\title{
PRAKTEK PERKAWINAN ADAT JUJURAN DI KABUPATEN ROKAN HULU RIAU DITINJAU DARI UNDANG-UNDANG NO. 1 TAHUN 1974
}

\author{
Aksar, Triwahyuni Lestari \\ aksar.bone@umri.ac.id
}

Fakultas Hukum Univ. Muhammadiyah Riau

ABSTRACT

The practice of marriage jujuran that occurred in Rokan Hulu Regency, Riau, and reviewed from Law No. 1 of 1974 in response to the provision uang hangus from the theoretical and practical aspects. The research method used is a descriptive qualitative method. The research approach carried out with a juridical approach is based on Law No. 1 of 1974. Data collection techniques used were observation and interviews. After doing research on these problems, giving uang hangus which is the core of the implementation of jujuran customs in Rokan Hulu Regency, Riau, if based on Law No. 1 of 1974 the gift of uang hangus in jujuran has the power and legal consequences, namely making a marriage contract process complicated, delayed, and can even cancel the marriage. In fact, the validity or nullification of a marriage is clearly regulated in Law No. 1 of 1974 concerning Marriage. Provision uang hangus unknown in Law No. 1 of 1974, as well as the practice of traditional marriage jujuran is not in accordance with statutory provisions.

Keywords: Marriage, Jujuran, Law No. 1. 1974

\begin{abstract}
ABSTRAK
Praktek perkawinan adat jujuran yang terjadi di Kabupaten Rokan Hulu Riau serta ditinjau dari Undang-undang No. 1 tahun 1974 dalam menyikapi pemberian uang hangus dari aspek teoritis dan prakteknya. Metode penelitian yang digunakan adalah metode kualitatif yang bersifat perskriptif. Adapun pendekatan penelitian yang dilakukan dengan pendekatan yuridis yaitu berdasarkan Undang-undang Nomor 1 Tahun 1974. Teknik pengumpulan data yang digunakan adalah, observasi dan wawancara (interview). Setelah dilakukan penelitian terhadap permasalahan tersebut, pemberian uang hangus yang merupakan inti dilaksanakannya adat jujuran di Kabupaten Rokan Hulu Riau, jika dari Undang-undang No. 1 tahun 1974 maka pemberian uang hangus di dalam adat jujuran mempunyai kekuatan dan akibat hukum, yaitu membuat suatu proses akad perkawinan menjadi rumit, tertunda, dan bahkan dapat membatalkan perkawinan. Padahal, sah atau batalnya suatu perkawinan sudah diatur jelas di dalam Undang-undang No. 1 tahun 1974 tentang Perkawinan. Pemberian uang hangus tidak dikenal dalam Undang-undang No. 1 tahun 1974, serta praktek perkawinan adat jujuran tidak sesuai dengan ketentuan peraturan perundang-undangan.
\end{abstract}

Kata kunci: Perkawinan Adat, Jujuran, Undang-undang No. 1 Tahun 1974 


\section{PENDAHULUAN}

Permasalahan sosial yang masih sering terjadi sekarang ini adalah pandangan masyarakat mengenai tata cara pelaksanaan perkawinan. Selama ini pelaksanaannya dikaitkan dengan kultur budaya atau adat yang dianut oleh masyarakat setempat. ${ }^{1}$ Akan tetapi tidak sedikit dari proses upacara perkawinan adat tersebut justru merumitkan. Padahal tujuan perkawinan adalah menciptakan ketenangan, ketentraman dan kesenangan (sakinah, mawaddah wa rahmah) bagi mempelai khususnya, keluarga dan masyarakat pada umumnya. ${ }^{2}$

Di Kabupaten Rokan Hulu Riau, ada pelaksanaan perkawinan berdasarkan adat yang disebut dengan adat menjujur atau jujuran. ${ }^{3}$ Dalam adat ini, ada beberapa

${ }^{1}$ Rizal Fahmi, "Pernikahan Adat Loloan Timur di Kabupaten Jembrana Studi Komparasi Antara Hukum Islam dan Hukum Adat", skripsi Fakultas Syariah dan Hukum UIN Sunan Kalijaga, 2015, hlm. 2.

${ }^{2}$ K. N. Sofyan Hasan, Warkum Sumitro, Dasar-dasar Memahami Hukum Islam di Indonesia, Surabaya: Usaha Nasional, 1994, hlm. 113.

3 Perkawinan adat jujuran adalah sebuah prosesi perkawinan khusus dengan mewajibkan melakukan pembayaran terlebih dahulu oleh keluarga calon mempelai laki-laki kepada keluarga calon mempelai perempuan. Perkawinan ini terjadi di masyarakat Rokan Hulu apabila mempelai perempuan berasal atau asli dari Rokan Hulu, tepatnya di Kecamatan Bangun Purba, namun tidak berlaku sebaliknya. Dalam prosesi pernikahan di daerah ini, ada suatu kekhususan tersendiri apabila mempelai perempuannya berasal atau penduduk asli, namun tidak ada kekhususan apapun apabila mempelai prianya yang penduduk asli. Berdasarkan hasil pra- rangkaian adat yang harus dipenuhi, sehingga baru dikatakan perkawinan mereka sah menurut adat. ${ }^{4}$ Selain itu, calon mempelai laki-lakinya harus membayar uang hangus. $^{5}$ - Pembayaran tersebut tidak termasuk dalam hitungan mahar. Pembayaran uang hangus dalam adat jujuran berbeda dengan mahar, mahar dalam hukum perkawinan sepenuhnya menjadi hak bagi mempelai wanita, hal ini juga ditegaskan dalam Pasal 32 Bab V Kompilasi Hukum Islam tentang mahar. Dalam penjelasannya disebutkan bahwa mahar diberikan langsung kepada calon mempelai wanita dan sejak itu menjadi hak pribadinya. Sedangkan uang hangus yang ada dalam penelitian yang dilakukan dengan mewawancarai salah seorang pemuka masyarakat Rokan Hulu.

${ }^{4}$ Adapun rangkaian-rangkaian yang sudah disepakati oleh masyarakat adat setempat untuk proses perkawinan yaitu: a) suluh-suluh ayie, b) ambil adat, c) antau tando d) akad, e) malam bainai, f) resepsi.

${ }^{5}$ Uang hangus adalah uang yang diberikan kepada pihak keluarga mempelai perempuan selain dari mahar. Jumlah uang yang harus diberikan tidak sedikit, karena menyangkut identitas dan etentitas pihak keluarga perempuan, terutama mamak/kepala suku adat. Padahal di dalam Undang-undang Perkawinan calon mempelai lakilaki hanya diwajibkan membayar mahar kepada calon mempelai perempuan. Selain itu juga pemberian uang hangus ditentukan oleh tingkat pendidikan calon mempelai perempuan yang hendak dinikahi. Calon mempelai perempuan yang hanya tamat SD tidak akan sama bayarannya dengan calon mempelai perempuan yang sudah strata-2 (S2) bahkan strata-3 (S3), bagi yang tamat SD sekurang-kurangnya harus membayar uang sejumlah Rp. 20.000.000,-, dan kalau sudah sarjana, maka bisa mencapai Rp. 100.000.000,-. Hal itu tergantung kepada pihak keluarga calon mempelai perempuan. 
adat jujuran bukan hak milik sepenuhnya untuk mempelai wanita, tapi untuk keluarga pihak wanita. Selain itu uang hangus tidak disebutkan ketika ijab kabul sebagaimana mahar disebutkan.

Oleh karena itu, permasalahan kebudayaan dan adat seperti adat jujuran tersebut tergolong unik dan tidak seperti perkawinan yang berlaku di Indonesia pada umumnya, sehingga peristiwa hukum ini menjadi sangat penting untuk diteliti dan perlu dikaji ulang lagi. Dengan berlandaskan aturan yang berlaku di Indonesia, harapannya penelitian ini nantinya akan memberikan informasi dan ilmu pengetahun tentang hukum perkawinan adat masyarakat Rokan Hulu dalam tinjauan Undang-undang Nomor 1 tahun 1974.

Atas dasar inilah, peneliti merasa tertarik untuk melakukan penelitian tentang perkawinan adat jujuran tersebut. Fokus penelitian ini ialah bagaimana legalitas dan kesakralan proses perkawinan seperti itu, dan melihat kesesuaian peraturan perkawinan sebagaimana dijelaskan di dalam Undang-undang Perkawinan. Oleh karena itu, peneliti mengangkat judul penelitian sebagai berikut: "Praktek Perkawinan Adat Jujuran di Kabupaten Rokan Hulu Riau Ditinjau dari Undang-undang No. 1 Tahun 1974?”.

\section{METODE PENELITIAN}

Untuk memperoleh langkah yang efektif dan hasil yang maksimal, penelitian ini menggunakan metode penelitian. Penelitian ini merupakan penelitian lapangan (field research), ${ }^{6}$ yaitu penelitian yang dilakukan dengan turun langsung ke lokasi obyek penelitian untuk mendapatkan datadata dan informasi yang berkaitan dengan praktik perkawinan jujuran pada perkawinan adat masyarakat Rokan Hulu Riau. Adapun sifat penelitian ini adalah perskriptif, yaitu suatu penelitian yang ditujukan untuk mendapatkan saran-saran mengenai apa yang harus dilakukan untuk mengatasi masalahmasalah tertentu seperti menilai apakah penerapan adat jujuran dalam perkawinan adat masyarakat Rokan Hulu yang dilakukan selama ini sudah sesuai dengan peraturan perundang-undangan yang berlaku.

Adapun pendekatan penelitian yang dilakukan dengan pendekatan yuridis yaitu dengan menggunakan dasar hukum perkawinan di Indonesia yaitu berdasarkan Undang-undang Nomor 1 Tahun 1974. Tujuannya untuk mengkaji hasil penelitian yang didapatkan dari fenomena praktik jujuran pada perkawinan adat masyarakat Rokan Hulu. Dalam penelitian ini, teknik pengumpulan data yang digunakan adalah

\footnotetext{
${ }^{6}$ Saifuddin Azwar, Metode Penelitian, Yogyakarta: Pustaka Pelajar, 1999, hlm. 21.
} 
observasi dan wawancara (interview). Selain itu dilakukan wawancara terarah, yang mana wawancara dilaksanakan secara bebas dan juga mendalam (in-depth), tetapi kebebasan ini tetap ada tidak terlepas dari pokok permasalahan yang akan ditanyakan kepada responden dan telah dipersiapkan sebelumnya oleh pewawancara. Jumlah responden tidak ditentukan banyaknya. Karakter utama dari wawancara ini adalah dilakukan secara bertahap dan pewawancara tidak harus terlibat dalam kehidupan sosial responden. ${ }^{7}$

\section{HASIL PENELITIAN}

A. Gambaran Umum Perkawinan Adat Masyarakat Rokan Hulu

Masyarakat Rokan Hulu, khususnya di Kecamatan Rambah dan Bangun Purba menilai bahwa perkawinan adat sangatlah penting. Perkawinan adat merupakan upacara-upacara dalam rangka perkawinan yang harus dipenuhi untuk sahnya sebuah upacara perkawinan selain mengikuti aturan agama dan negara. Jika upacara perkawinan yang dilakukan hanya dengan akad nikah yang dilegalkan oleh Kepala Kantor Urusan Agama (KUA), maka akan mendapatkan penilaian yang kurang baik, karena menurut pandangan masyarakat Rokan Hulu, akad

\footnotetext{
${ }^{7}$ M. Burhan Bungin, Penelitian Kualitatif, Jakarta: Kencana, 2008, hlm. 110.

40 Journal Equitable
}

nikah tanpa diikuti dengan prosesi perkawinan adat menimbulkan kecurigaankecurigaan dari pihak masyarakat. Selain itu juga adat istiadat akan menjadi pembeda dan ciri khas suku bangsanya masing-masing. Demikian juga yang terpenting, adat dan upacara perkawinan ini dinilai sebagai hal yang luhur, peninggalan nenek moyang yang harus dipatuhi yang akan membawa ketertiban dan kesejahteraan bagi masyarakat yang menjalankannya.

Menurut adat masyarakat Rokan Hulu, dalam proses perkawinan, orang tua memegang peranan penting, mereka memegang inisiatif untuk terlaksananya perkawinan tersebut. Dengan demikian, orang tua juga mempunyai tujuan dan kepentingan ketika mengawinkan anak mereka. Adapun tujuan dalam melakukan perkawinan bagi masyarakat Rokan Hulu adalah dengan mengawinkan anak mereka, berarti orang tua akan dapat melanjutkan keturunan, orang tua berkeinginan tidak hanya sebatas punya anak, namun mereka juga menginginkan keturunannya tidak terputus sampai anak mereka saja, tapi akan terus berkelanjutan. Selain itu, mengawinkan anak mereka, berarti orang tua telah dapat memenuhi salah satu kewajiban dan tanggungjawab terhadap anak mereka, mereka telah menunjukkan jalan yang benar 
dan mencegah anak mereka dari perbuatan yang dilarang oleh agama.

Orang tua juga beranggapan jika anaknya melangsungkan perkawinan berarti orang tua telah membangunkan rumah tangga bahagia bagi anak mereka berdasarkan tuntunan agama Islam. Oleh karena itu, kalau anaknya belum dapat berdiri sendiri, maka orang tua akan selalu membantu baik berupa materi, ataupun nasehat dalam membangun rumah tangga anak mereka berdasarkan ajaran agama Islam.

Bagi masyarakat Rokan Hulu, mempertemukan jodoh anak mereka sampai melangsungkan perkawinan menjadi kewajiban bagi orang tua. Orang tua akan bahagia jika bisa melakukan itu kepada anaknya. Mengawinkan anak mereka berarti mempertemukan dua keluarga yang berbeda, ini berarti juga mengawinkan anak menyebabkan keluarga pihak laki-laki dan perempuan yang menjadi keluarga besar dimana anak mereka menjadi tali pengikatnya.

\section{B. Gambaran atau Bentuk Praktek Perkawinan Adat Jujuran}

Perkawinan jujuran atau jelasnya perkawinan yang di dalamnya ada pemberian (pembayaran) uang hangus, pada umumnya berlaku di lingkungan masyarakat hukum adat yang mempertahankan garis keturunan bapak (laki-laki). Pemberian uang hangus pada adat jujuran dilakukan oleh pihak kerabat (marga/suku) calon suami kepada pihak kerabat calon istri, sebagai tanda pengganti pelepasan mempelai wanita keluar dari kewargaan adat persekutuan hukum bapaknya, pindah dan masuk ke dalam persekutuan hukum suaminya. Hal ini berarti setelah dilakukannya perkawinan maka isteri tunduk dan patuh terhadap aturan hukum adat suaminya. Ini berarti dalam konsep perkawinan jujuran yaitu adanya suatu perpindahan kewargaan adat.

Pada umumnya, dalam perkawinan jujuran sangat mementingkan kehidupan rumah tangga, sehingga senang atau susah selama berumah tangga harus dijalani dengan semaksimal mungkin. Pemberian jujuran yang diwajibkan adalah untuk mengembalikan keseimbangan magis yang semula goyah menjadi kuat. Perkawinan jujuran dijumpai pada masyarakat patrineal. Ciri-ciri perkawinan jujuran adalah patrilokal, artinya istri bertempat tinggal dikediaman suami atau keluarga suami. ${ }^{8}$

Ada yang harus dipahami dalam tradisi perkawinan jujuran, bahwa uang hangus yang diberikan di dalam adat jujuran bukanlah mas kawin atau mahar menurut

Soerojo Wignjodipoero, Pengantar dan Asas Hukum Adat, (Bandung: Alumni, 1989), hlm. 128 
hukum Islam, karena uang hangus adalah kewajiban adat ketika dilakukan pelamaran yang harus dipenuhi oleh keluarga mempelai pria kepada keluarga mempelai wanita untuk dibagikan kepada kepala kerabatan (adat/suku) pihak wanita. Sedangkan mas kawin atau mahar adalah kewajiban agama ketika dilaksanakan akad nikah yang harus dipenuhi oleh mempelai pria untuk wanita (pribadi).

Pada awalnya, pelaksanaan atau praktek perakwinan dengan memakai adat jujuran, tidak mengenal adanya istilah uang hangus, namun kemudian akhir-akhir ini, terjadi sebuah perubahan pada dataran sosial masyarakat Rokan Hulu. Masyarakat Rokan Hulu menuntut keharusan adanya uang hangus pada sebuah perkawinan. Hal ini sangat bersinggungan langsung dengan perubahan kebutuhan dan ketergantungan finansial, dalam artian pemberian calon suami kepada calon isteri bertambah menjadi dua, yaitu selain adanya kewajiban memberikan mahar (yang sudah diatur dalam perundang-undangan dan $\mathrm{KHI}$ ) juga ada keharusan untuk memberikan uang hangus (bagian dari praktek perkawinan adat jujuran).

Menurut peneliti, adanya keharusan untuk membayar uang hangus berfungsi sebagai bentuk tanggung jawab calon suami kepada orang tua isteri karena telah

menjadikan anaknya sebagai isteri yang akan pendampingi hidupnya sampai akhir hayat. Selain itu juga, untuk meringankan biaya kebutuhan resepsi pernikahan yang dilaksanakan di tempat calon isteri. Sedangkan jika calon suami hendak melangsungkan resepsi pernikahan di rumahnya juga, maka tidak ditanggung melalui uang hangus tersebut. Data yang ditemukan di lapangan, uang yang diberikan dalam adat jujuran itu adalah berdasarkan status calon isteri, yang mana semakin tinggi status sosial calon isteri dalam masyarakat atau tingkat pendidikannya, maka semakin tinggi nilai nominal uang hangus yang diajukan pihak perempuan kepada pihak laki-laki, tanpa melihat bagaimanapun latar belakang dan kemampuan calon suami yang hendak menikah tersebut.

\section{Analisis Perkawinan Adat Jujuran Masyarakat Rokan Hulu}

Pelaksanaan perkawinan khususnya
masyarakat di Indonesia cenderung
dilakukan dengan hukum adat. Dalam Pasal
2 Undang-undang No. 1 Tahun 1974 tentang
perkawinan, menjelaskan perkawinan
haruslah mengikuti aturan yang ditetapkan
oleh agama mempelai. Akan tetapi, dalam
praktek perkawinan di Indonesia selain
mengikuti peraturan agama, adat juga
menjadi hal yang penting, seperti yang selalu


dipraktekkan oleh masyarakat Rokan Hulu ketika mengadakan perkawinan yang penuh dengan berbagai adat istiadat, baik sebelum, sesaat, ataupun sesudah perkawinan dilaksanakan.

Di Rokan Hulu, upacara perkawinan merupakan suatu hal yang sakral menjadi keharusan bagi masyarakat Rokan Hulu untuk melakukannya dengan segenap kepercayaan dan keyakinan yang dimilikinya. Hal ini sudah menjadi warisan leluhur yang terus menerus dilakukan sampai sekarang. Setiap masyarakat Rokan Hulu yang ingin melaksanakan pernikahan, maka sudah menjadi keharusan untuk melakukan tradisi ini, karena sudah menjadi kebiasaan di masyarakat tersebut, seperti yang dituturkan oleh Bapak Teuku Rusli selaku salah satu pemangku adat dari suku Seratuih dengan gelar Dt. Paduko Sade di Rokan Hulu, beliau katakan:

Tradisi ini sudah menjadi darah daging yang turun temurun dari nenek moyang, jadi ada rasa cemas jika tidak dipraktekkan adat tersebut. Tapi tidak ada rasa terpaksa, melainkan sudah menjadi kesadaran masing-masing siapa yang ingin menikah. Siapun orangnya, maka dia harus mengikuti adat, kalaupun tidak dilakukan, maka dia dianggap bukan keturunan dari situ, artinya dia bukan dari daerah tersebut. ${ }^{9}$

\footnotetext{
${ }^{9}$ Hasil wawancara dengan Bapak Teuku Rusli selaku salah satu pemangku adat dari suku Seratuih dengan gelar Dt. Paduko Sade di Rokan Hulu pada tanggal 3 Juni 2019.
}

Dari hasil wawancara tersebut, maka dapat disimpulkan bahwa kepatuhan masyarakat terhadap tradisi sangat tinggi dan kesadaran mereka untuk tetap selalu menjaga dan melestarikan tradisi mereka seperti tidak pernah pudar. Anggapan mereka, jika tradisi ini ditinggalkan, maka akan muncul perasaan tidak nyaman jika tidak melaksanakannya. Demikian juga tidak ada satu masyarakatpun yang melanggar atau menyalahi aturan tersebut, walaupun zaman sekarang sudah maju (modern) dibanding zaman tradisional dulu, tetapi mereka selalu mengikuti apa saja yang dilakukan oleh leluhurnya karena takut kualat jika tidak melaksanakan tradisi tersebut. Dalam penelitian ini ialah terjadi interaksi antar masyarakat terhadap adat jujuran yang dilakukan secara terus menerus dalam waktu yang lama.

Adapun yang menjadi pertanyaan dalam adat jujuran ini adalah adanya keharusan membayar uang hangus. Uang hangus adalah uang yang diberikan kepada pihak keluarga mempelai perempuan selain mahar. Padahal aturan hukum dalam perkawinan, yang diharuskan untuk diberikan kepada pihak keluarga mempelai perempuan adalah mahar. Dalam Pasal 30 Kompilasi Hukum Islam dijelaskan bahwa calon mempelai pria hanya diharuskan 
membayar mahar kepada calon mempelai perempuan yang mana jumlah, bentuk dan jenisnya disepakati oleh kedua belah pihak. Sebagaimana dijelaskan sebelumnya bahwa sebenarnya yang wajib membayar mahar itu bukan calon mempelai laki-laki, tetapi mempelai laki-laki, karena kewajiban itu baru ada setelah berlangsung akad nikah. Demikian pula yang menerima bukan calon mempelai wanita, tetapi mempelai wanita, karena dia baru berhak menerima mahar setelah adanya akad nikah.

Jumlah uang yang harus diberikan dalam adat jujuran tidak ada yang sedikit, karena menyangkut identitas dan etentitas pihak keluarga perempuan, terutama mamak/pemangku adat/kepala suku adat atau datuk-datuk adat. Hal ini bukan berarti bahwa kehormatan seorang perempuan dinilai atau sebanding dengan nilai materi, tetapi uang hangus menjadi suatu bentuk penghormatan kepada perempuan. Padahal peneliti menanggapi bahwa di dalam Undang-undang Perkawinan calon mempelai laki-laki hanya diwajibkan membayar mahar kepada calon mempelai perempuan.

Selain itu juga pemberian uang hangus ditentukan oleh tingkat pendidikan calon mempelai perempuan yang hendak dinikahi. Calon mempelai perempuan yang hanya tamat SD tidak akan sama bayarannya dengan calon mempelai perempuan yang sudah strata-2 (S2) bahkan strata-3 (S3), bagi yang tamat SD sekurang-kurangnya harus membayar uang sejumlah $\mathrm{Rp}$. 20.000.000,-, dan kalau sudah sarjana, maka bisa mencapai Rp. 100.000.000,-. Hal itu tergantung kepada pihak keluarga calon mempelai perempuan. ${ }^{10}$

Hal ini disebabkan adanya tingkatan kemampuan manusia yang berbeda-beda dalam memberinya. Jangankan pemberian uang hangus, mahar saja harus disertai dengan kerelaan dan persetujuan masingmasing pihak yang akan menikah untuk menetapkan jumlahnya. Oleh karena itu, Islam menyerahkan jumlah mahar itu berdasarkan kemampuan masing-masing orang, atau keadaan dan tradisi keluarga atau masyarakat setempat. Seharusnya jika diberlakukan uang hangus, juga berdasarkan kemampuan masing-masing orang atau keadaan orang tersebut, bukan memaksakan untuk membayar sesuai patokan yang sudah ditetapkan berdasarkan tingkat pendidikan calon mempelai perempuan.

Memang sebenarnya, terkait penentuan jumlah pemberian mahar tidak ada disebutkan di dalam Undang-undang Perkawinan atau menyalahi undang-undang tersebut, tapi dapat mengacu kepada peraturan lain yang sudah ditetapkan sebagai

\footnotetext{
10 Berdasarkan hasil pra-penelitian yang dilakukan dengan mewawancarai salah seorang pemuka masyarakat Rokan Hulu, Ibid.
} 
peraturan dalam pelaksanaan perkawinan. Hal ini sebagaimana dijelaskan dalam Pasal 31 Kompilasi Hukum Islam (KHI), menyatakan bahwa penentuan mahar berdasarkan atas kesederhanaan dan kemudahan yang dianjurkan oleh ajaran Islam.

Selanjutnya, pemberian uang hangus memang tidak menyalahi Undang-undang Perkawinan, karena tidak disebutkan secara langsung di dalam undang-undang tersebut, akan tetapi dengan adanya tujuan perkawinan sebagai jalan untuk membentuk keluarga, tentu tidak harus dengan cara memberatkan calon mempelai laki-laki. Padahal mereka yang ingin melangsungkan pernikahan adalah karena sudah adanya satu tujuan dan satu harapan dapat membentuk keluarga yang kekal dan bahagia.

Ketika melakukan penelitian dilapangan, ditemukan bahwa sering terjadinya perselisihan dan pertentangan terhadap penentuan jumlah uang hangus yang akan dibayarkan, bahkan diluar kesanggupan pihak laki-laki untuk membayar uang hangus tersebut. Padahal hakikatnya, dalam perkawinan tidak ada unsur memberatkan. Begitu juga dengan mahar yang harus diberikan. Jangankan uang hangus, maharpun tidak ada batasan mengenai jumlah minimal atau maksimal mahar, tidak ada juga batasan dalam bentuk maharnya, baik berupa harta atau jasa selama tidak bertentangan dengan peraturan perundang-undangan yang berlaku.

Pada akhirnya, adat jujuran ini melahirkan beberapa fenomena, seperti tertundanya pernikahan atau sampai batalnya pernikahan. Seperti yang dijelaskan oleh Bapak Admiral Lubis selaku pemerintah daerah Rokan Hulu (Camat Bangun Purba):

Pernikahan dengan adat jujuran ini memang menghasilkan dampak yang besar, ada yang dapat membuat orang yang ingin menikah, tidak jadi menikah atau dibatalkan, dikarenakan tidak mampu membayar uang hangus yang telah ditawarkan oleh kepala adat pihak perempuan, tapi ada juga yang hanya tertunda saja, karena pihak laki-laki meminta untuk memberikan waktu untuk mencukupkan uang yang diminta. ${ }^{11}$

Selain berakhir dengan batalnya pernikahan, dampak dari pelaksanaan adat jujuran ini juga ada yang hanya menunda waktu pernikahan saja, sampai pihak lakilaki mampu memenuhi sesuai dengan permintaan. Hal ini terjadi kepada keluarga Bapak Tamroni yang anaknya ingin menikah dengan perempuan yang memakai adat jujuran. Ketika diwawancarai, Pak Tamroni mengatakan:

\footnotetext{
11 Hasil wawancara dengan Bapak Admiral Lubis selaku Pemerintah Daerah Rokan Hulu (Camat Bangun Purba) pada tanggal 19 Juni 2019.
} 
Anak saya ini mau sekali menikah dengan perempuan pilihannya, tapi pihak keluarga perempuan meminta uang hangus di atas kemampuan kami. Pihak perempuan sudah ditetapkan jumlahnya, jadi kami minta ditangguhkan waktunya. Sebenarnya kami tidak sanggup melihat anak kami menunggu seperti itu. Tapi karena sayang dengan anak, terpaksa menunggu, karena juga mereka mau menunggu, jadi sebisa mungkin kami kumpulkan uangnya dulu. $^{12}$

Dari keterangan di atas, pihak lakilaki tetap ingin melaksanakan pernikahan dengan perempuan pilihannya tersebut, maka dia akan berusaha semaksimal mungkin untuk bisa memenuhi permintaanya. Namun ketika pihak perempuan menentukan jumlah uang hangus yang ternyata tidak mampu memberikan jumlah tersebut dalam waktu yang cepat. Pada akhirnya, setelah bermusyawarah, maka diberikanlah waktu tunggu untuk memenuhi jumlah yang diminta, hal ini menyebabkan tertundanya pernikahan mereka.

D. Analisis Perbandingan Konsep Antara Undang-undang Perkawinan dengan Perkawinan Adat Jujuran Masyarakat Rokan Hulu

\footnotetext{
${ }^{12}$ Hasil wawancara dengan Bapak Tamroni (selaku orang tua yang anaknya memakai adat jujuran) pada tanggal 3 Juni 2019
}

Ada persamaan konsep antara Undang-undang Perkawinan dengan perkawinan adat jujuran, hal ini juga menjadi sisi positif dalam hal pernikahan ketika pembahasan ini masuk dalam ranah Undang-undang - Perkawinan dalam pembahasan peran dan fungsi hukumnya, yaitu:

\section{Tradisi Pernikahan Adat Jujuran} dapat Menekan Pernikahan Usia Dini

Dalam kebiasaan masyarakat Rokan Hulu, pernikahan adat jujuran ini dapat menentukan jadi atau tidaknya suatu pernikahan yang sudah direncanakan. Sebagaimana disebutkan sebelumnya, bahwa prosesi adat jujuran harus menempuh berbagai macam tahapan, seolah-olah terkesan menyulitkan. Bagi pasangan yang belum memasuki usia dewasa, tentu mereka tidak akan mau melangsungkan pernikahan. Selain itu, ada kewajiban untuk memberikan uang hangus dalam jumlah yang cukup banyak. Hal ini membuat calon mempelai laki-laki harus benar-benar mempersiapkan diri (fisik maupun materi). Sebagaimana dituturkan oleh Bapak Admiral Lubis selaku Pemerintah Daerah:

Terpenting itu dalam adat jujuran adalah calon mempelai harus sudah matang persiapannya, baik persiapan 
mental, fisik, maupun persiapan keuangan. Tentu yang bisa melakukannya adalah orang-orang yang sudah bekerja dan sudah masuk usia dewasa, yaitu tahu yang boleh dilakukan dan mana yang tidak boleh dilakukan. $^{13}$

Sehingga dapat dipahami bahwa tradisi pernikahan adat jujuran ini dapat menekan pernikahan usia dini, artinya pasangan yang belum siap secara mental maupun finansial tentu tidak akan mau melaksanakan pernikahan. Hal ini sesuai dengan perintah Undang-undang Perkawinan Pasal 7 ayat 1 yang disebutkan bahwa:

"Perkawinan hanya diizinkan jika pihak pria sudah mencapai umur 19 (sembilan belas) tahun dan pihak wanita sudah mencapai umur 16 (enam belas) tahun". ${ }^{14}$

Tujuan dari ditetapkannya batasan umur ini adalah untuk menjaga kelangsungan kedua pasangan suami istri dan juga menjaga kehidupan pasangan ketika dalam masa pernikahan.

\section{Tradisi Pernikahan Adat Jujuran} dapat Menekan Terjadinya

\section{Perkawinan Paksa}

13 Hasil wawancara dengan Bapak Admiral Lubis selaku Pemerintah Daerah Rokan Hulu (Camat bangun Purba) pada tanggal 4 Juni 2019

14 Bunyi Pasal 7 ayat 1 Undang-undang No. 1 tahun 1974.
Dalam perkawinan adat jujuran, sangat mementingkan kehidupan rumah tangga, sehingga calon suami atau calon istri yang ingin menikah adalah benarbenar pilihan meraka, tanpa ada paksaan dari pihak manapun. Terlebih lagi bagi seorang laki-laki yang ingin mempersunting seorang perempuan, dalam adat jujuran, jika bukan pilihannya, maka akan dirasa sangat rugi ketika mengeluarkan uang hangus dengan jumlah yang banyak, akan tetapi nikahnya dipaksa. Dengan pemahaman seperti itu, maka pernikahan adat jujuran dapat menekan terjadinya perkawinan paksa.

Hal ini sejalan dengan Undangundang Perkawinan, dalam Undangundang No. 1 Tahun 1974 Pasal 6 ayat 1 disebutkan:

"Perkawinan harus didasarkan atas persetujuan kedua calon mempelai". 15

Adanya persetujuan kedua calon mempelai sebagai salah satu syarat perkawinan dimaksudkan agar supaya setiap orang dengan bebas memilih pasangannya untuk hidup berumahtangga dalam perkawinan. Jadi pernikahan yang dipaksa oleh orangtuanya belum tentu tepat bagi

\footnotetext{
${ }^{15}$ Undang-undang No. 1 Tahun 1974 Pasal 6 ayat 1
} 
anaknya. Agar pernikahan yang dilaksanakan nantinya berjalan dengan lancar, maka biarkanlah anak memilih dengan pilihannya sendiri, karena pernikahan yang dibangun di atas dasar keterpaksaan, maka akan mengganggu keharmonisan dalam berumahtangga.

\section{Tradisi Pernikahan Adat Jujuran} dapat Menekan Angka Perceraian

Kesamaan konsep lainnya adalah tradisi pernikahan adat jujuran ini dapat menekan angka perceraian. Alasannya pernikahan adat jujuran ini mengharuskan isteri yang sudah dinikahi untuk ikut dengan suami. Isteri juga diharuskan untuk patuh terhadap suami, karena budaya yang diwariskan adalah budaya patrineal, artinya semua akibat hukum yang terjadi selama pernikahan, lebih diarahkan kepada pihak suami. Hal ini akan menekan angka perceraian, karena sangat minim sekali terjadi persengketaan dan perselisihan. Sebagaimana penjelasan yang sama disampaikan oleh Bapak H. Fhatanalia Putra:

"Pastinyo kalo urang tu lah sah jadi suami isteri, tontu isteri harus tinggal di tompek suami, indo bulieh membantah, harus nurut samo suami, karena suami tu kan kepala keluarga, yo harus di tinggikan sadahan dan didahulukan salangkah". 16

Kalau mereka sudah sah menjadi suami isteri, maka isteri harus tinggal di tempat suami, tidak boleh membantah, harus menurut sama suami, karena suami adalah kepala keluarga yang harus di tinggikan sadahan dan didahulukan salangkah.

Selain itu juga, tradisi pernikahan adat jujuran sangat mementingkan musyawarah, sehingga semua persoalan dan permasalahan yang terjadi, baik di luar pernikahan maupun di dalam pernikahan, harus diselesaikan secara musyawarah. Dalam musyawarah ini melibatkan tokoh-tokoh adat dan pemangku adat. Para tokoh inilah yang akan membahas dan menyelesaikan permasalahan yang terjadi, dan sangat mendahulukan perdamaian. Bagaimanapun, usaha pemangku adat dalam menyelesaikan masalah adalah dengan jalan perdamaian, bukan perpecahan atau perceraian dari setiap pihak. Sebagaimana dijelaskan oleh Bapak Amri selaku pemangku adat suku Ampu Kecil yang bergelar Dt. Sutan Alam:

Jika ada terjadi sengketa, maka kedua pihak isteri dan suami harus didudukkan, dicari dimana letak

\footnotetext{
${ }^{16}$ Hasil wawancara dengan Bapak H. Fhatanalia Putra selaku Pemerintah Daerah Rokan Hulu (Camat Rambah) pada tanggal 4 Juni 2019
} 
permasalahannya, usaha kita sebagai orang tua adat dan pemangku adat berupaya untuk merukunkan mereka kembali, bagaimanapun harus mereka kembali lagi, tidak boleh terjadi perpisahan atau bahkan mereka cerai. ${ }^{17}$

Hal ini juga akan menekan angka perceraian, karena sangat minim sekali terjadi persengketaan dan perselisihan. Pada akhirnya akan menghambat alasan mereka dijadikan alasan untuk mengajukan perceraian. Sebagaimana disebutkan di dalam Undang-undang No. 1 Tahun 1974, bahwa di dalam undangundang itu disebutkan bahwa perceraian hanya dikatakan sah setelah ada putusan pengadilan yang berkekuatan hukum tetap. Namun tidak mudah untuk menggugat ataupun memohon cerai ke pengadilan. Harus ada alasan-alasan yang cukup menurut hukum. Alasanalasan tersebut diatur dalam Pasal 39 ayat 2 Undang-undang No. 1 tahun 1974 tentang Perkawinan Jo Pasal 19 Peraturan Pemerintah No. 9 tahun 1975 tentang Pelaksanaan Undang-undang Nomor 1 Tahun 1974 tentang Perkawinan, yakni sebagai berikut:

17 Hasil wawancara dengan Bapak Amri selaku pemangku adat atau kepala adat suku Ampu Kecil yang bergelar Dt. Sutan Alam pada tanggal 1 Juni 2019. a. Salah satu pihak berbuat zina atau menjadi pemabuk, pemadat, penjudi dan lain sebagainya yang sukar disembuhkan

b. Salah satu pihak meninggalkan yang lain selama 2 (dua) tahun berturutturut tanpa izin pihak yang lain dan tanpa alasan yang sah atau karena hal lain diluar kemampuannya

c. Salah satu pihak mendapat hukuman penjara 5 (lima) tahun atau hukuman yang lebih berat setelah perkawinan berlangsung

d. Salah satu pihak melakukan kekejaman atau penganiayaan berat yang membahayakan terhadap pihak lain

e. Salah satu pihak mendapat cacat badan atau penyakit yang mengakibatkan tidak dapat menjalankan kewajiban sebagai suami/isteri

f. Antara suami dan isteri terus menerus terjadi perselisihan dan pertengkaran dan tidak ada harapan akan hidup rukun lagi dalam berumah tangga

Jadi, tradisi adat jujuran ini dapat mencegah perceraian dengan alasan antara suami isteri terus menerus terjadi perselisihan dan pertengkaran. Sehingga tidak ada alasan yang cukup menurut 
hukum, dan pada akhirnya gugatan cerai tidak bisa dikabulkan pengadilan.

4. Tradisi Pernikahan Adat Jujuran dapat Menekan Terjadinya Poligami

Ciri-ciri perkawinan jujuran adalah patrilokal, artinya istri bertempat tinggal dikediaman suami atau keluarga suami, hal ini menjadikan seorang istri sepenuhnya milik suami dan ikut kepada suami. Sehingga ketika suami hendak menikah lagi dengan perempuan lain atau ingin melakukan poligami, maka sangat sulit untuk membagi waktunya dengan istri yang lain. Selain itu suami akan berfikir panjang kalau ingin menikah lagi. Sebagaimana diketahui, bahwa menikah itu butuh modal yang sangat besar, apalagi terikat dengan adat jujuran karena harus memberikan uang hangus, padahal sudah mengeluarkan modal yang sangat besar dengan adanya pemberian uang hangus dengan istri pertama.

Hal ini sejalan dengan Undangundang Perkawinan, undang-undang perkawinan memang membolehkan poligami, tapi syarat poligami tidak mudah. Syarat poligami diatur dalam Undang-undang Perkawinan Pasal 4 ayat 2 dan Pasal 5 ayat 1 dan 2, isinya adalah:

\section{Pasal 4 ayat 2:}

Pengadilan dimaksud dalam ayat (1) pasal ini hanya memberi izin kepada seorang suami yang akan beristeri lebih dari seorang apabila

1. Isteri tidak dapat menjalankan kewajibannya sebagai isteri;

2. Isteri mendapat cacat badan atau penyakit yang tidak dapat disembuhkan;

3. Isteri tidak dapat melahirkan keturunan

\section{Pasal 5 ayat 1 dan 2:}

(1) Untuk dapat mengajukan permohonan kepada Pengadilan sebagaimana dimaksud dalam Pasal 4, ayat (1) Undang-undang harus dipenuhi syarat-syarat sebagai berikut:

1. Ada persetujuan dari isteri/isteri-isteri

2. Adanya kepastian bahwa suami mampu menjamin keperluan hidup isteri-isteri dan anak-anak mereka

3. Adanya jaminan bahwa suami akan berlaku adil terhadap isteri-isteri dan anak-anak mereka

(2) Persetujuan yang dimaksud pada ayat (1) huruf a pasal ini tidak diperlukan bagi seorang suami apabila isteri/isteriisterinya tidak mungkin diminta persetujuannya dan tidak dapat menjadi pihak dalam perjanjian, atau apabila tidak ada kabar dari isterinya selama sekurang- 
kurangnya 2 (dua) tahun, atau karena sebab-sebab lainnya yang perlu mendapat penilaian dari Hakim Pengadilan.

Poligami menjadi persoalan problematis di Indonesia, namun di dalam adat jujuran, mencoba untuk meminimalisir problematika tersebut.

Selain itu, adat jujuran juga menimbulkan kesan negatif, menimbulkan nilai yang kurang baik dalam pelaksanaannya, contohnya sebagai berikut:

1. Memberikan kesan materialistis, maksudnya adat merupakan jati diri bagi masing-masing kelompok masyarakatnya, begitupun dengan adat jujuran yang menjadi ciri khas bagi masyarakat Rokan Hulu, namun adat ini jika dikritisi, akan memberikan kesan bahwa terlalu mementingkan materi, buktinya pemberlakukan uang hangus yang jumlahnya sangat besar. Hal ini terkesan bahwa adat ini sangat materialistis.

2. Meyakini nilai-nilai leluhur dengan berlebih, hal ini terlihat bahwa sebagian masyarakat masih keliru dalam memaknai sebuah tradisi adat. Banyak dari masyarakat yang memaknai tradisi adar dengan berlebihan, artinya jika tidak dilakukan adat tersebut, maka akan menimbulkan sesuatu yang tidak diinginkan/kualat. Seharusnya, dengan seiring berkembangnya zaman, maka pemahaman-pemahaman seperti itu sudah tidak ada lagi, sudah mulai berubah dan hanya dijadikan sebagai sebuah tradisi warisan leluhur. Terlebih lagi sekarang sudah adanya aturan dan peraturan dalam pelaksanaan prosesi pernikahan yang legal dan diakui negara. Boleh dilestarikan, tapi tidak merusak pemahaman kita bahwa itu satu-satunya pedoman dalam melaksanakan prosesi pernikahan.

3. Tumbuhnya kompetitas yang berlebihan, hal ini tidak jarang terjadi dalam melaksanakan adat jujuran. Dengan adanya adat jujuran, maka terjadi persaingan antar orang tua perempuan terhadap lingkungan masyarakat sekitar. Agar status sosial keluarga mereka terpandang baik, maka pelakasanaan jujuran menjadikan penentunya, artinya semakin besarnya uang hangus yang diterima oleh keluarga pihak perempuan, maka semakin mengangkat status keluarga tersebut ditengah masyarakat. Pada dasarnya, yang menjadi titik penting ialah terlaksananya pernikahan dengan baik dan kedua belah pihak saling rida dan ikhlas dalam memberikan jumlah uang hangus tersebut. 
Jadi, dalam perspektif studi adat dan budaya, hal ini lebih mengarahkan kepada struktur yang berlaku dimasyarakat. Dengan analisis ini, perangkat tidak hanya dinilai menyatukan kehidupan sosial atau budaya yang menyubordinasikan sekumpulan orang atas kelompok, melainkan proses yang membangun segala bentuk tindakan, hubungan sosial, dan tatanan sosial ${ }^{18}$ dalam suatu masyarakat.

\section{E. Legalitas Perkawinan Adat Jujuran} Berdasarkan Undang-Undang

\section{Perkawinan}

Adat yang berkembang di tengahtengah masyarakat, ada yang baik dan ada pula yang buruk. Dalam teori hukum dasar, adat yang dapat diterima hanyalah adat yang baik, sementara adat yang buruk harus ditolak atau bahkan dihilangkan. ${ }^{19}$ Persoalannya adalah bagaimana cara mengetahui, mana adat yang baik dan mana adat yang buruk. Dalam hal ini, para ulama telah menetapkan persyaratan-persyaratan tertentu. Abdul Wahhab Khallaf misalnya mengatakan bahwa adat yang baik adalah adat yang tidak bertentangan dengan Hadis

18 M. Ridhah Taqwa, "Menyoal Praktek Kekuasaan Di Arena Pendidikan Berbasis Keagamaan Suatu Perspektif Cultural Studies", dimuat dalam Prosiding Simposium Nasional Mahasiswa Pascasarjana Tahun 2008: 100 Tahun Kebangkitan Nasional Dalam Berbagai Perpektif, Yogyakarta, 16-17 Mei 2008.

19 Umar Syihab, Hukum Islam dan Transformasi Pemikiran, Semarang: Bina Utama, 1996, hlm. 32. dan al-Qur'an, serta tidak menghalalkan yang haram dan tidak pula menggugurkan kewajiban, sedangkan adat yang buruk adalah sebaliknya. ${ }^{20}$ Dengan demikian, adat kebiasaan seperti keberlakuan uang hangus dalam perkawinan adat jujuran yang ditetapkan sebagai hukum adat adalah prinsip serta praktik uang hangus harus berjalan lurus dengan Undang-undang Perkawinan sebagai legal hukum.

Dalam ajaran Islam, ada kaidah yang dapat dijadikan sebagai landasan, yang artinya "suatu kebiasaan bisa dijadikan sebuah hukum". Maksudnya adalah bahwa adat kebiasaan dapat ditetapkan sebagai hukum. Kaidah ini memaksudkan gagasan yaitu menghargai praktik lokal sebagai perwujudan dari rasa keadilan masyarakat setempat. Dalam batas-batas tertentu, dalam cakupan peraturan perundang-undangan, praktik lokal itu diangkat menjadi sumber kebenaran dari aturan. Dengan kata lain, bahwa suatu kejadian dalam masyarakat, manakala telah dapat ditetapkan sebagai hukum atau dapat dijadikan sebagai sumber hukum, asal saja tidak bertentangan dengan peraturan perundang-undangan yang berlaku. $^{21}$

20 Abdul Wahhab Khallaf, 'Ilmu Ushul al-Fiqh, Beirut: Dar al-Fikr, 1978, hlm. 89.

21 Abdul Mun'im Saleh, Hukum Manusia Sebagai Hukum Tuhan, cet. ke-1, Yogyakarta: Pustaka Pelajar, 2009, hlm. 285. 
Sobhi Mahmassani secara lebih rinci menetapkan syarat-syarat diterimanya suatu adat kebiasaan menjadi sebagai hukum: ${ }^{22}$

1. Adat kebiasaan harus diterima oleh watak yang baik, yaitu bisa diterima oleh akal dan sesuai dengan perasaan yang waras atau dengan pendapat umum.

2. Hal-hal yang dianggap sebagai adat harus terjadi berulangkali

3. Adapun yang dianggap berlaku sebagai perbuatan sosial adat adat kebiasaan yang lam bukan yang terakhir

4. Suatu kebiasaan tidak boleh diterima apabila diantara dua belah pihak terdapat syarat yang berlainan, sebab adat itu kedudukannya sebagai yang implisit yang sudah dengan sendirinya

5. Adat kebiasaan hanya dapat dijadikan sebagai alasan hukum apabila tidak bertentangan dengan ketentuan peraturan perundangundangan yang berlaku

Singkatnya, menurut Mahmassani bahwa adat kebiasaan yang dapat diterima sebagai hukum hanyalah adat kebiasaan yang sesuai dengan peraturan perundangundangan yang sudah ditetapkan dan disepakati. Sebaliknya, segala yang bertantangan dengan peraturan perundangundangan, maksud dan tujuannya, sama sekali tidak bisa diakui sebagai hukum.

Dalam pandangan di atas, kiranya dapat diambil kesimpulan bahwa suatu adat dapat diterima sebagai bagian dari hukum, paling tidak dengan dua syarat. Pertama, tidak bertentangan dengan peraturan perundang-undangan yang secara tegas telah menetapkan suatu ketentuan hukum. Kedua, tidak bertentangan dengan kemaslahatan. Kerangka berpikir inilah yang dalam praktik perkawinan adat jujuran harus menjadi pedoman dalam menyelesaikan persoalan masyarakat Rokan Hulu yang berkaitan dengan adat istiadat mereka.

Sehubungan dengan itu, pemberian uang hangus dalam perkawinan adat jujuran yang terjadi di Rokan Hulu merupakan suatu tahapan proses yang harus dilaksanakan. Namun pada prakteknya, ketidakmampuan memenuhi uang hangus dalam jumlah tertentu dapat saja membatalkan suatu rencana akad nikah. Sedangkan di dalam peraturan yang berlaku tentang perkawinan, pemberian suami kepada isterinya dalam perkawinan adalah mahar yang demikian harus ada meskipun jumlahnya sangat

${ }^{22}$ Sobhi Mahmassani, Filsafat at-Tasyri' fi al-Islam, alih bahasa Ahmad Sudjono, cet. ke-1, Bandung: PT Al-Maarif, 1976, hlm. 262-264. 
minim, serta dianjurkan untuk berlandaskan kepada Kompilasi Hukum mempermudah dalam pemberian mahar. ${ }^{23}$

Sementara dalam perundang-
gan kontemporer tersebut dijelaskan Islam (KHI). undangan kontemporer tersebut dijelaskan secara ringkas bahwa mahar adalah pemberian suami kepada isteri. Hak mahar serta dalam menentukan jumlahnya adalah mutlak menjadi hak isteri. Sebaliknya, orang tua atau keluarga lain dari isteri tidak boleh menuntut uang apapun dari suami atau calon suaminya. Sehingga keterlibatan wali dalam jumlah mahar tidak berhak menghalangi akad nikah. ${ }^{24}$

Memberi mahar oleh pihak laki-laki tidak berarti menghargai atau membeli wanita, tetapi sebagi simbolik bahwa lakilaki akan memberi nafkah dan mahar sebagai pendahuluan tanda kecintaan dan kesucian hati dan kerelaan memberi kepada isteri. Kemudian mahar tersebut menjadi hak milik isteri, ia merdeka mempergunakan untuk apa saja yang ia kehendaki. Demikian itu sebagai bentuk kewajiban pertama yang diberikan oleh suami kepada isterinya dalam perkawinan menurut aturannya, yaitu hanya berupa mahar sesuai dengan kemampuan laki-laki atau calon suami. Sebagaimana kewajiban mahar ini kepada pihak suami

23 Khairuddin Nasution, Hukum Perkawinan I, (Yogyakarta: ACAdeMIA \& TAZZAFA, 2005) hlm. 166.

${ }^{24}$ Ibid.

Dalam Pasal 30 Kompilasi Hukum Islam (KHI) dijelaskan bahwa calon mempelai pria wajib membayar mahar kepada calon mempelai perempuan yang jumlah, bentuk dan jenisnya disepakati oleh kedua belah pihak. ${ }^{25}$ Dari ketentuan tersebut, maka pemberian uang hangus haruslah dilihat kesesuaiannya dengan peraturan yang berlaku, kemudian kemaslahatan dalam penentuan jumlah uang hangus tidak membuat suatu akad nikah terulur bahkan sampai gagal. Terlebih jika mahar sendiri pun dalam aturannya dianjurkan untuk tidak memberatkan. Sehingga layak jika dalam penentuan pemberian uang hangus tidak terdapat nilai komersil dengan berkaca pada ketentuan mahar dalam peraturan perundang-undangan.

Sementara jika dilihat berdasarkan kemaslahatan, maka ada keharusan bagi orang-orang terdekat (pihak keluarga) untuk membantu perkawinan laki-laki bujang atau wanita yang tidak bersuami jika seseorang telah mampu untuk menikah, maka pihak keluarganya segera mungkin untuk menikahkannya selain untuk menghindari kemudaratan, menikah merupakan ibadah. Dengan demikian, wali yang berperan besar dalam penentuan jumlah uang hangus

\footnotetext{
${ }^{25}$ http://hukum.unsrat.ac.id/uu/uu_1-74.htm
} 
seharusnya tidak memperumit terlaksananya akad nikah. Tapi memberikan kemudahan agar terlaksananya pernikahan dengan baik.

Perkawinan bagi masyarakat Indonesia adalah suatu yang sakral dan mempunyai tujuan yang luhur, dan tidak lepas dari ketentuan-ketentuan peraturan perundang-undangan yang telah ditetapkan negara. Melalui perkawinan, pemerintah memberi banyak kemudahan dengan rukun dan syarat-syaratnya, sehingga seorang wali atau orang tua tidak boleh menunda-nunda perkawinan perempuan yang berada di bawah perwaliannya atau pengasuhannya. Meskipun perkawinan semata-mata tidak hanya berkaitan dengan kepatuhan aturan yang berlaku, tetapi juga menyentuh persoalan adat kebiasan, tentu hal demikian tidak diharapkan jika keluarga mempersulit terjadinya perkawinan bagi perempuan di bawah perwaliannya atau anak di bawah pengasuhan orang tuanya.

Dalam hal perkawinan, peraturan perundang-undangan Indonesia telah mengatur bagaimana perempuan sangat dihargai dan diperhatikan kedudukannya, yaitu dengan memberikan mahar sebagai hak mutlak perempuan yang akan dinikahi, demikian juga dalam menentukan besar atau kecilnya jumlah yang diinginkan bukan hak walinya, ataupun pihak keluarga wanita. $^{26}$ Termasuk pula kerelaan atas sedikit banyaknya jumlah mahar yang diterima. Hak ini ada pada wanita yang akan menikah untuk menentukan jumlah maharnya, buka hak bagi keluarganya. Tetapi setelah menjadi hak penuh wanita, ia boleh memberikan kepada sebagian keluarganya, atau ia menyimpannya sendiri. ${ }^{27}$

Dari pemaparan di atas dapat diambil kesimpulan bahwa, jika uang hangus yang demikian bukanlah sesuatu yang wajib, tetapi menuntut atau diharuskan pada pihak laki-laki untuk diberikan kepada pihak keluarga perempuan itu menghambat ataupun memberatkan terjadinya perkawinan, padahal antara kedua calon mempelai saling mencintai, maka patut dipersoalkan kesesuaian prinsip uang hangus serta praktik perkawinan adat jujuran dalam tinjauan perundang-undangan. Praktik perkawinan adat jujuran yang di dalamnya memberlakukan uang hangus yang demikian tidak sesuai dengan ketentuan peraturan perundang-undangan, baik itu menyulitkan, memberatkan ataupun nantinya dapat mengundang kemudaratan yang lain. Tentu

${ }^{26}$ Mohammad Asmawi, Nikah dalam Perbincangan dan Perbedaan, Yogyakarta: Darussalam, 2004, hlm. 159-160.

27 Mohamad Fauzil Adhim, Kupinang Engkau Dengan Hamdalah, cet. ke-7, Yogyakarta: Mitra Pustaka, 1999, hlm. 230. 
praktik yang kiranya dapat mendatangkan kemudaratan itu harus dicegah.

Adapun praktik perkawinan adat jujuran yang di dalamnya memberlakukan uang hangus memang jika dilihat dari tujuannya adalah meringankan beban pihak perempuan untuk memenuhi kebutuhan resepsi. Akan tetapi jika penentuan pemberlakukan uang hangus yang demikian menyebabkan kerumitan dan terulurnya waktu akad perkawinan yang seharusnya dilaksanakan lebih cepat lebih baik, maka sebaiknya praktik perkawinan adat jujuran yang demikian haruslah lebih memperhitungkan kerusakannya. Sebab kerusakan dapat meluas dan menjalar kemana-mana sehingga dapat mengakibatkan kesengsaraan. Intinya, masalah perkawinan merupakan masalah kemanusiaan dan kerelaan masing-masing pihak sehingga perlu tidak ada satupun pihak yang merasa diberatkan sebab perkawinan merupakan kepentingan kedua belah pihak.

\section{KESIMPULAN}

Dari pembahasan-pembahasan yang telah peneliti sampaikan di atas, maka dapat ditarik kesimpulan bahwa persoalan perkawinan, dimanapun itu berada dan pada masyarakat manapun, termasuk masyarakat Rokan Hulu adalah merupakan masalah sosial. Perkawinan tidak hanya menjadi urusan individu-individu antara kedua pasangan tersebut, akan tetapi perkawinan juga melibatkan banyak pihak, yaitu keluarga dari pihak laki-laki dan keluarga dari pihak perempuan beserta masyarakat sekitar.

Perkawinan adat jujuran adalah sebuah prosesi perkawinan khusus dengan mewajibkan melakukan pembayaran terlebih dahulu oleh keluarga calon mempelai lakilaki kepada keluarga calon mempelai perempuan. Perkawinan ini terjadi di masyarakat Rokan Hulu apabila mempelai perempuan berasal atau asli dari Rokan Hulu, tepatnya di Kecamatan Bangun Purba, namun tidak berlaku sebaliknya. Dalam prosesi pernikahan di daerah ini, ada suatu kekhususan tersendiri apabila mempelai perempuannya berasal atau penduduk asli, namun tidak ada kekhususan apapun apabila mempelai prianya yang penduduk asli. Berdasarkan hasil pra-penelitian yang dilakukan dengan mewawancarai salah seorang pemuka masyarakat Rokan Hulu.

Adapun yang menjadi berbeda dengan perkawinan yang lainnya adalah pada perkawinan adat jujuran ini, calon mempelai laki-lakinya harus membayar uang hangus. Uang hangus adalah uang yang diberikan kepada pihak keluarga mempelai perempuan selain dari mahar. Jumlah uang 
yang harus diberikan tidak sedikit, karena menyangkut identitas dan etentitas pihak keluarga perempuan, terutama mamak/kepala suku adat. Padahal di dalam Undang-undang Perkawinan calon mempelai laki-laki hanya diwajibkan membayar mahar kepada calon mempelai perempuan. Selain itu juga pemberian uang hangus ditentukan oleh tingkat pendidikan calon mempelai perempuan yang hendak dinikahi. Calon mempelai perempuan yang hanya tamat SD tidak akan sama bayarannya dengan calon mempelai perempuan yang sudah strata-2 (S2) bahkan strata-3 (S3), bagi yang tamat SD sekurang-kurangnya harus membayar uang sejumlah Rp. 20.000.000,-, dan kalau sudah sarjana, maka bisa mencapai Rp. 100.000.000,-. Hal itu tergantung kepada pihak keluarga calon mempelai perempuan.

Seharusnya jika diberlakukan uang hangus, juga berdasarkan kemampuan masing-masing orang atau keadaan orang tersebut, bukan memaksakan untuk membayar sesuai patokan yang sudah ditetapkan berdasarkan tingkat pendidikan calon mempelai perempuan. pemberian uang hangus memang tidak menyalahi Undangundang Perkawinan, karena tidak disebutkan secara langsung di dalam undang-undang tersebut, akan tetapi dengan adanya tujuan perkawinan sebagai jalan untuk membentuk keluarga, tentu tidak harus dengan cara memberatkan calon mempelai laki-laki. Padahal mereka yang ingin melangsungkan pernikahan adalah karena sudah adanya satu tujuan dan satu harapan dapat membentuk keluarga yang kekal dan bahagia.

\section{REFERENSI}

\section{Buku}

Adhim, Mohamad Fauzil, Kupinang Engkau Dengan Hamdalah, cet. ke-7, Yogyakarta: Mitra Pustaka, 1999.

Asmawi, Mohammad, Nikah dalam Perbincangan dan Perbedaan, Yogyakarta: Darussalam, 2004.

Azwar, Saifuddin, Metode Penelitian, Yogyakarta: Pustaka Pelajar, 1999.

Bungin, M. Burhan, Penelitian Kualitatif, Jakarta: Kencana, 2008.

Hasan, K. N. Sofyan, Warkum Sumitro, Dasar-dasar Memahami Hukum Islam di Indonesia, Surabaya: Usaha Nasional, 1994.

Khallaf, Abdul Wahhab, 'Ilmu Ushul alFiqh, Beirut: Dar al-Fikr, 1978.

Mahmassani, Sobhi, Filsafat at-Tasyri' fi alIslam, alih bahasa Ahmad Sudjono, cet. ke-1, Bandung: PT Al-Maarif, 1976.

Nasution, Khoiruddin, Hukum perkawinan I, Yogyakarta: ACAdeMIA \& TAZZAFA, 2005.

Saleh, Abdul Mun'im, Hukum Manusia Sebagai Hukum Tuhan, cet. ke-1, Yogyakarta: Pustaka Pelajar, 2009. 
Syihab, Umar, Hukum Islam dan

Transformasi Pemikiran, Semarang: Bina Utama, 1996.

Wignjodipoero, Soerojo, Pengantar dan Asas Hukum Adat, Bandung: Alumni, 1989

\section{Hasil Penelitian}

Fahmi, Rizal, "Pernikahan Adat Loloan Timur di Kabupaten Jembrana Studi Komparasi Antara Hukum Islam dan Hukum Adat", skripsi Fakultas Syariah dan Hukum UIN Sunan Kalijaga, 2015.

Taqwa, M. Ridhah, "Menyoal Praktek Kekuasaan Di Arena Pendidikan Berbasis Keagamaan Suatu Perspektif Cultural Studies", dimuat dalam Prosiding Simposium Nasional Mahasiswa Pascasarjana Tahun 2008: 100 Tahun Kebangkitan Nasional Dalam Berbagai Perpektif, Yogyakarta, 2008. 